\title{
Squamous cell carcinoma of the rectum
}

INSERM

\section{Source}

INSERM. (1999). Orphanet: an online rare disease and orphan drug data base. Squamous cell carcinoma of the rectum. ORPHA:424002

Squamous cell carcinoma (SCC) of rectum is a rare epithelial tumor of the rectum, arising from squamous cells in the rectal epithelium, without the presence of squamous-lined fistulous tracts in the rectum or a proximal extension of SCC of anal or gynecological origin. The reported symptoms are often nonspecific, such as anorexia, weight loss, lower abdominal pain, rectal bleeding and changes of bowel habits. 